\title{
Development of Sustainable Cotton Poly Blended Woven Fabric with Anti Pilling Finish
}

\author{
Jothi Manikandan A and Ramesh G* \\ Department of Textile Chemistry, India
}

ISSN: 2578-0271

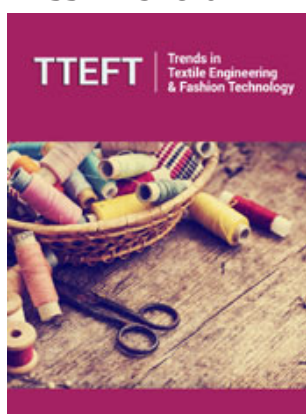

*Corresponding author:

Manikandan A and Ramesh G*

Submission: March 18, 2019

Published: 制April 01, 2019

Volume 5 - Issue 1

How to cite this article: Jothi Manikandan A, Ramesh G. Effect of Blend Ratio on Quality Characteristics of Polyester/Cotton Blended Ring Spun Yarn. Advancements Bioequiv Availab.5(1). TTEFT.000602.2019.

DOI: 10.31031/TTEFT.2019.05.000602.

Copyright@ Ramesh G, This article is distributed under the terms of the Creative Commons Attribution 4.0 International License, which permits unrestricted use and redistribution provided that the original author and source are credited.

\begin{abstract}
In this study, development of sustainable cotton poly blended woven fabric made from pre-consumer \& post-consumer waste suitable for apparels with anti-pilling finish has been compared with regular non-sustainable fabrics. The need aroused to develop this recycled cotton poly blended fabric came to create a sustainable product by taking cotton-from garment cutting waste, rejected garments, used garments \& Poly- from used PET bottles. The fabric made from this development was having some amount of pilling due to recycled yarns. To overcome the pilling of recycled cotton poly blended fabrics, anti-pilling agents to be applied in the bulk. This development study will provide the solution of sustainable fabrics which is

commercially viable for apparel industry in terms of cost, lead time and fashion aspirations in coming days, reduce carbon footprints, reduce energy \& water consumption, Lessened demand for dyes, create eco-friendly \& sustainable textiles
\end{abstract}

Keywords: Pre-consumer \& post-consumer waste; Anti-pilling finish; Carbon foot prints; Energy; Water saving; Reduction in dye stuff

\section{Sustainability}

\section{Introduction}

Sustainability is the process of maintaining change in a balanced fashion, in which the exploitation of resources, the direction of investments, the orientation of technological development and institutional change are all in harmony and enhance both current and future potential to meet human needs and aspirations.

a) Sustainable development is the development that meets the needs of the present without compromising the ability of future generations to meet their own needs.

b) Under the accordance of sustainability, recycled clothing upholds the principle of the "Three R's of the Environment": Reduce, Reuse, and Recycle, as well as the "Three Legs of Sustainability": Economics, Ecology, and Social Equity (Figure 1).

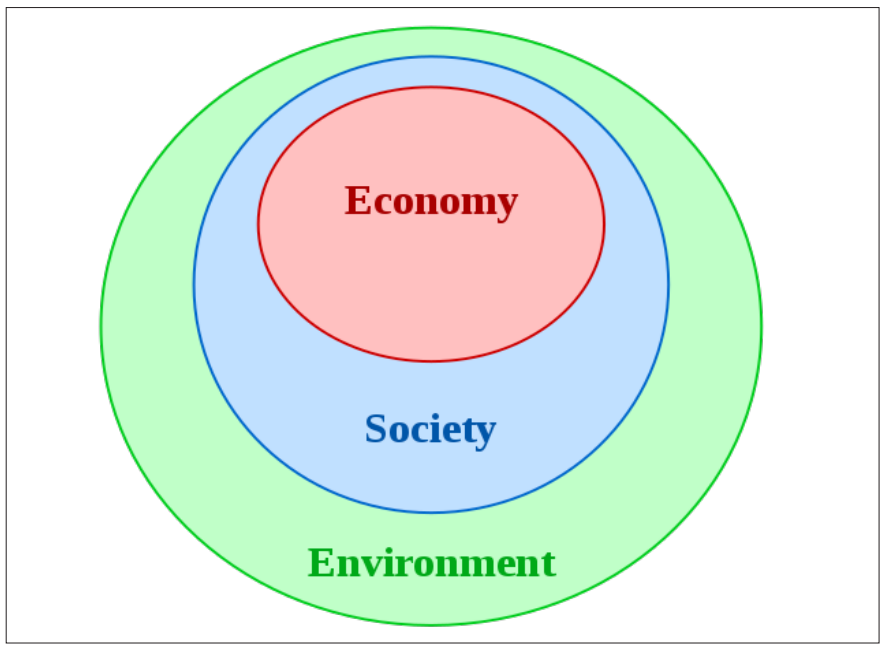

Figure 1: 


\section{Material \& Method}

Sustainable clothing refers to fabrics derived from eco-friendly resources, such as sustainably grown fiber crops or recycled materials [1].

Table 1: Testing standards \& type of tests.
Material: Post consumer apparels, used PET bottles.

Method: manufacturing process which requires lessened amount of water \& highly ecofriendly (Table 1 ).

\begin{tabular}{|c|c|c|}
\hline \multicolumn{3}{|c|}{ Testing Standards \& Type of Tests } \\
\hline Tests (Test methods) & & Testing requirements \\
\hline $\begin{array}{l}\text { A) Color fastness to washing (Test } \\
\text { method: ISO105: } 1997 \text { CO6) A2S; }\end{array}$ & a. General: & CC:4/CS 4-5 \\
\hline $\begin{array}{l}\text { B) Color fastness to rubbing (Test } \\
\text { method: ISO } 105 \text { X12 1995) }\end{array}$ & a. General & DRY:4/WET 3 \\
\hline $\begin{array}{l}\text { D) Dimensional Stability to washing } \\
\text { (shrinkage) (ref: BSEN:25077 / } \\
26330 ; 94 \text { ) }\end{array}$ & a. WOVENS: & Mill-made/ Power loom: $-3 /+2 \%$ \\
\hline E) Pilling resistance test & \multirow{3}{*}{ a. General } & Regular fabric; 4 \\
\hline $\begin{array}{l}\text { IS013945-1 (ICI Pill Box Method) } \\
\text { After one wash }\end{array}$ & & anti-pill :4-5 \\
\hline wovens 36000revs & & Grade: 3 \\
\hline \multirow{3}{*}{ F) Tensile Strength IS013934-2:1999 } & a. light weight-voile, georgette & (VOILE, GEORGETTE 65N)/loose-85N/regular fit others-100N \\
\hline & $\begin{array}{l}\text { b. Medium weight/Cambric, poplin } \\
\text { fabric }\end{array}$ & $100 \mathrm{~N}$ \\
\hline & $\begin{array}{l}\text { c. Regular Top-Mill made/twill/cordu- } \\
\text { roy fabric }\end{array}$ & $110 \mathrm{~N}$ \\
\hline \multirow{3}{*}{ J) Tear strength } & $\begin{array}{c}\text { light weight < } 100 \text { gsm (GEORGETTE/ } \\
\text { VOILE) }\end{array}$ & voile/georgette-6.5 N/OTHERS 7.5N \\
\hline & $\begin{array}{l}\text { medium weight-100-180gsm (CAM- } \\
\text { BRIC/POPLIN) }\end{array}$ & $9.17 \mathrm{~N}$ \\
\hline & heavy weight $>180$ gsm & $12 \mathrm{~N}$ \\
\hline $\begin{array}{l}\text { I) Appearance after } 3 \text { Washes\# (ref: } \\
\text { BSEN:25077 / 26330;94) }\end{array}$ & \multirow[t]{2}{*}{ General } & Color Fastness as per relevant Performance Standard \\
\hline \#WET LOAD @3KG load for 30mins. & & No Damage of trims/accessories \\
\hline \multirow{3}{*}{$\begin{array}{l}\text { K) Seam Slippage \& Strength- where } \\
\text { ver applicable (ref: ISO 13936- } \\
\text { 1/13935-2) }\end{array}$} & $\begin{array}{l}\text { a. Woven -Tops light weight-voile, chif- } \\
\text { fon, georgette }\end{array}$ & $\begin{array}{l}\text { S.Slippage }(6 \mathrm{~mm} \text { opening) } 50 \mathrm{~N} \\
\text { S.Strength:60N }\end{array}$ \\
\hline & $\begin{array}{c}\text { b. Woven-Top Medium weight/cambric, } \\
\text { poplin }\end{array}$ & $\begin{array}{l}\text { S.Slippage:(6mm opening) } 65 \mathrm{~N} \\
\text { S.Strength: } 80 \mathrm{~N}\end{array}$ \\
\hline & c. Woven-top Regular Top-Mill made & $\begin{array}{l}\text { S.Slippage } 80 \mathrm{~N} \\
\text { S.Strength: } 115 \mathrm{~N}\end{array}$ \\
\hline
\end{tabular}

\section{Benefits of $100 \%$ recycled polyester}

By creating a product that is comfortable and $100 \%$ recycled, to rethink plastic waste and repurpose it in a way that simultaneously benefits ourselves and the community. It has a superior hand feel, currently the best in the recycled polyester market, and "Rethink" is the only company doing $100 \%$ recycled polyester ring spun. Furthermore, 90\% less water is used in using recycled polyester than virgin polyester, dramatically decreasing Rethink's negative environmental impact. Because our products are $100 \%$ recycled polyester, Rethink can maximize environmental benefits and our garments can offer the use of sublimation printing and may be garment recycled [2].

\section{Recycled Cotton}

Cotton recycling prevents unneeded wastage and can be a more sustainable alternative to disposal. Recycled cotton may come from older, previously used garments or by textile leftovers which are then spun into new yarns and fabrics. There are some notable limitations of recycled cotton, including separation of materials that are cotton/polyester mix. There may also be limits to durability in using recycled cotton.

\section{Benefits of cp blends}

A fabric made from a cotton poly blend combines the strengths of the two fibers. Cotton poly garments are breathable, wrinkle free, 
tear-resistant, and can be fashioned into abrasion-resistant fabrics, like canvas. While not as inexpensive as pure polyester, cotton poly blends do tend to cost less than comparable garments made of $100 \%$ cotton and they provide much more comfort. The previously mentioned $80 / 20$ blend of cotton and polyester is the most popular for work garments, particularly because of price \& durability. The actual fabric resulted out of this development was having some amount of pilling due to recycled yarns.

\section{Anti-pilling agents to reduce pilling on cotton/polyester fabric}

Pilling is a phenomenon that has a long cause trouble in textile industry. It is the formation of pills or knops on the surface of woven or knitted fabrics caused by friction and abrasion [3]. Pilling proceeds in two stages. Individual fibres start protruding from the surface of the fabric and form an uneven nap. The protruding fibres rolls together become entangled and felt together to form knops (Figure 2). To eliminate this problem in fabric stage, the antipilling finishing treatments can be applied to the recycled fabrics developed [4]. Different chemical finishing approaches are made to prevent pills from accumulating on fabric surface such as application of polymers by padding and coating techniques, reduction in the strength of fiber to reduce pilling to cause the pills to fall off from the material as soon as they get formed and application of enzymes (bio finish) to $100 \%$ cotton textiles to cause removal of loose fibers in the yarn to reduce pilling tendency (Figure 3).

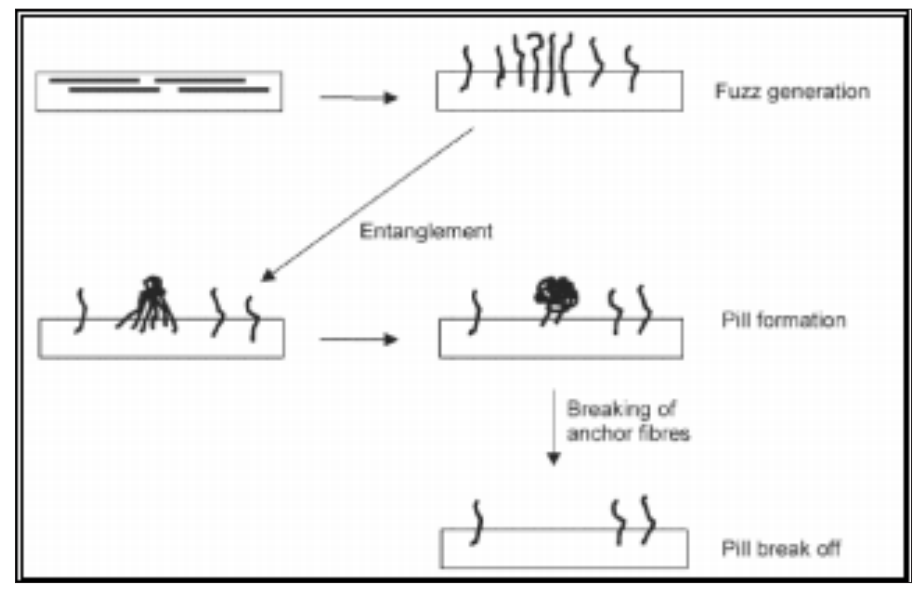

Figure 2: Pilling Formation..

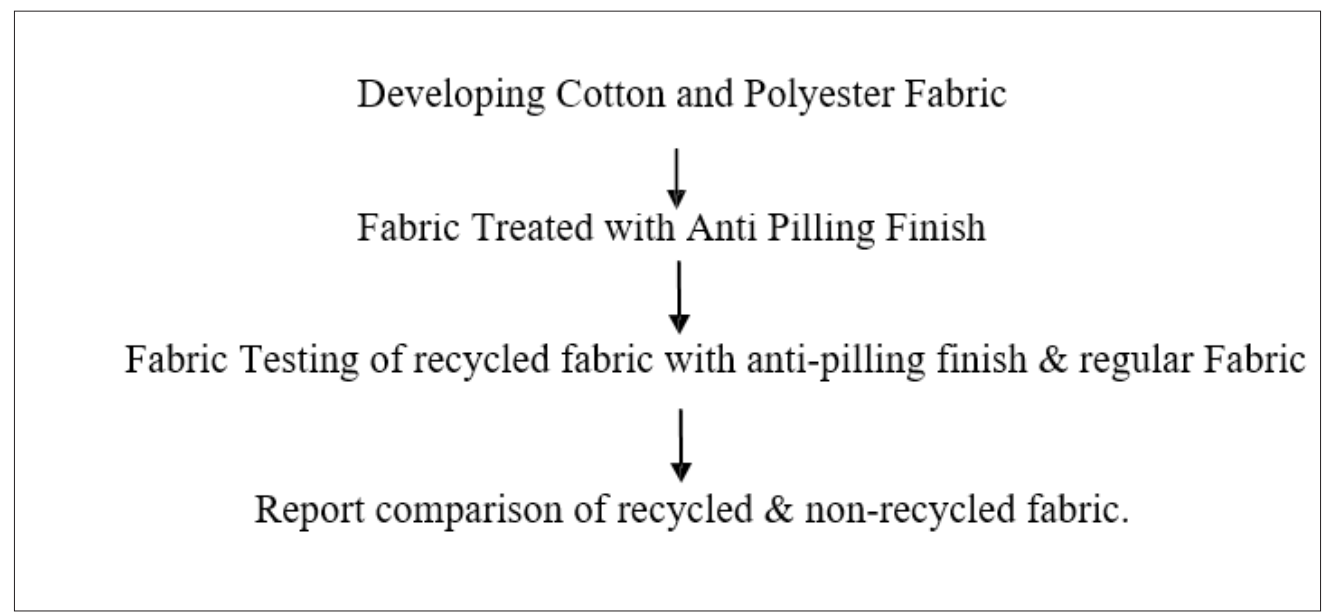

Figure 3: Process sequence flow chart.

\section{Result}

Attached Fabric Package Test reports of both normal cotton fabrics \& recycled fabric with anti-pilling finish -both are passing with the satisfactory results. Below are the standard testing requirements.

\section{Discussion}

While we look at all the possible ways of promoting sustainable products for value retail industry which is need of an hour for the future generation to live safely, considering the fact every apparel manufactured using freshly produced fabrics leaves a huge threat to environment, hence it is imperative that we all look at the possibilities of adopting apparel made from Sustainable fabrics without any second thought. Since the yarns are made from reused garments \& reused pet bottles some amount of

a) Yarn thick and thin are visible in the fabric made,

b) In terms of yarn shades, it will have look which is similar to heather shades (melange look) rather than looking a solid colour \& the getting the exact shades as per requirement will be a limitation, 
we can look at this as a fashion element (as an effect rather than defect) keeping the fashion quotient in mind of value fashion retail, considering the fact of Sustainable fabric with great advantages in terms of price, lead time as a socio-economic product.

\section{Conclusion}

This study is carried out to find out an alternative fabric instead of looking at the regular method of producing a fabric with the usage of recycled apparels \& recycled pet bottles there by we can avoid complete dyeing process. Hence the same can be recommended to adopt to value retail brands to have great Sustainable products at a comparatively lesser rate (around 25\%-30\%) than the regular fabric price as there is no yarn dyeing charges, we get the ready colored yarns from spinning there by price advantage is possible. Since these are with cotton (80\%)/polyester (20\%), it has great characteristics of wearing comfort \& crease resistance properties as well with good amount of luster to it. As mentioned before though it has some amount of yarn thick, thin \& shade solidity limitations the same can be still commercially accepted keeping the advantages of sustainability, cost, lead time, fashion aspirations in coming days, reduce carbon footprints, reduce energy \& water consumption, Lessened demand for dyes, create eco-friendly \& sustainable textiles.

\section{References}

1. Qamar T, Nasir M, Saleem M (2012) Effect of different anti pilling agents to reduce pilling on polyester/ cotton fabric. J Chem Soc Pak 34(1): 1-5.

2. (2015) A research about the effect of the antipilling treatments on different structured cotton fabrics. Tekstil Ve Konfeksiyon 25(1): 54-60

3. Win Aung, Aung T, Hnin S (2018) Survey of the anti-pilling treatment of polyester/cotton fabric 4(2): 1-5.

4. Shamima A, Azharul I (2015) Exploration on pilling attitudes of cotton polyester blended single jersey knit fabric after mechanical singeing. Science Innovation 3(1): 18-21. 